\title{
Analytical and Environmental Chemistry in the Framework of Risk Assessment and Management: The Lagoon of Venice as a Case Study
}

\author{
Giulio Pojana, Andrea Critto, Christian Micheletti, Claudio Carlon, Francesco Busetti, and \\ Antonio Marcomini*
}

\begin{abstract}
Prevention of toxic pollutant discharge and remediation of contaminated sediments and soils are topics increasingly addressed by the scientific community and the stakeholders. The research activity carried out on the lagoon of Venice highlights the crucial role played by analytical and environmental chemistry in assessing the environmental behavior of chemicals (i.e. occurrence level, transformation, ultimate fate) and exposure of human and environmental targets to pollutants. The extrapolation from analytical data to decisional steps was accomplished by data treatment (descriptive and multivariate statistics, spatial statistics), environmental modeling (e.g. partitioning bioaccumulation models and linear regression models), environmental risk assessment (ERA), and a GIS-based Decision Support System (DSS). Results obtained by this integrated approach supported analytical and environmental chemistry by improving the selection of priority pollutants, optimizing sampling design, and identifying critical environmental pathways. Both uncertainty minimization and cost saving of the overall decision process could be achieved. Selected results are presented here on the application of the proposed approach to the contaminated sediments of the lagoon of Venice and to the brownfield of the Porto Marghera industrial district. Both well-known persistent pollutants (e.g. polychlorinated dioxins/furans (PCDD/Fs), polychlorinated biphenyls (PCBs), polycyclic aromatic hydrocarbons (PAHs), metals and metalloids, and aromatic surfactants and their metabolites), as well as new classes of pollutants (e.g. endocrine disrupting compounds, EDCs) were investigated. The analytical data indicated that the most persistent and toxic organic and inorganic chemicals were found mainly in bottom sediments (especially those near the Porto Marghera industrial district), while substances such as surfactants and their metabolites and EDCs occurred mainly in water and were redistributed over the whole lagoon. Exposure characterization allowed Environmental Risk Assessment (ERA) to be undertaken, including the estimation of risk for both human and environmental health. The ERA procedure, developed according to a tiered approach, was applied to contaminated soils of the Porto Marghera industrial district. The ecological risk associated with contaminated lagoon sediments for the benthic community and aquatic food web was also assessed, resulting in a significant risk posed especially by mercury, cadmium and PAHs. Finally, a risk-based decision support system (DSS) for the rehabilitation of the Porto Marghera contaminated site was developed, which included environmental risk and remediation technologies.
\end{abstract}

Keywords: Analytical chemistry - Environmental chemistry - Lagoon of Venice - Persistent and toxic substances · Risk assessment

${ }^{*}$ Correspondence: Prof. A. Marcomini Department of Environmental Sciences University of Venice Calle Larga S. Marta 2137 I-30123 Venezia

Tel.: +390412348548

Fax: + 390412348584

E-Mail: marcom@unive.it

\section{Introduction}

The occurrence in the environment of toxic and persistent substances posing a risk for human health and ecosystems is a relevant environmental problem for post-industrialized societies.

Several national and international conventions and regulations are already enforced to prevent the release of these pollutants into the environment and to undertake the clean-up of contaminated sites. Moreover, increasing attention is paid to understand the trans-frontier mobility of persistent and toxic substances, within a global climatic change perspective.

The scientific and technological research in this field ranges from the development of innovative analytical procedures, which aims to determine the contamination levels in environmental compartments of concern, up to the definition of 
decision support systems (DSS), summarizing and integrating the overall available information, and the associated uncertainty, to drive the decision-making process of stakeholders.

Although data from analytical and environmental chemistry play often a critical role since they are the raw information used to assess the distribution of pollutants in the environment and the associated potential risk for human health and ecosystems, extrapolation from analytical data to decision steps is a challenging issue. This extrapolation requires the development and integration of different and complementary assessment tools, especially those concerning data spatial analysis (geostatistics, multivariate statistics) and environmental risk assessment (exposure models)

The present work provides a survey of selected activities carried out over the last ten years on the lagoon of Venice proving the need to integrate exposure assessment, obtained by analytical-environmental chemistry and statistical-spatial analysis, with risk assessment and environmental management.

\section{The Case Study}

The lagoon of Venice is a large shallow coastal ecosystem (approx. $550 \mathrm{~km}^{2}$, average depth: approx. $1 \mathrm{~m} \pm 0.3 \mathrm{~m}$, average salinity: $31 \pm 4 \%$ ) located in the Northern Adriatic Sea, including canals, marshes, and islands, and connected with the Adriatic Sea by three inlets (Fig 1) [1]. This transition ecosystem is subjected to heavy anthropogenic pressures, such as nutrient and pollutant discharge, which increased greatly during the last century, following urban, industrial, and agricultural development. The main pollutant sources for this coastal environment are:

1) raw sewage from the historical center of Venice (approx. 110,000 equivalent inhabitants, including tourists);

2) effluents from municipal sewage treatment plants (approx. 400,000 equivalent inhabitants);

3) non-agricultural and agricultural runoff conveyed into the lagoon by rivers, canals, and streams (total discharge: $31.5 \mathrm{~m}^{3} / \mathrm{s}$ ) [1];

4) atmospheric emissions and treated industrial effluents from Porto Marghera, a large industrial district (approx. 3000 ha wide) located on the lagoon border;

5) groundwater seepage and contaminated soil erosion from the Porto Marghera district, which has been included in a list of contaminated sites of national relevance [2].

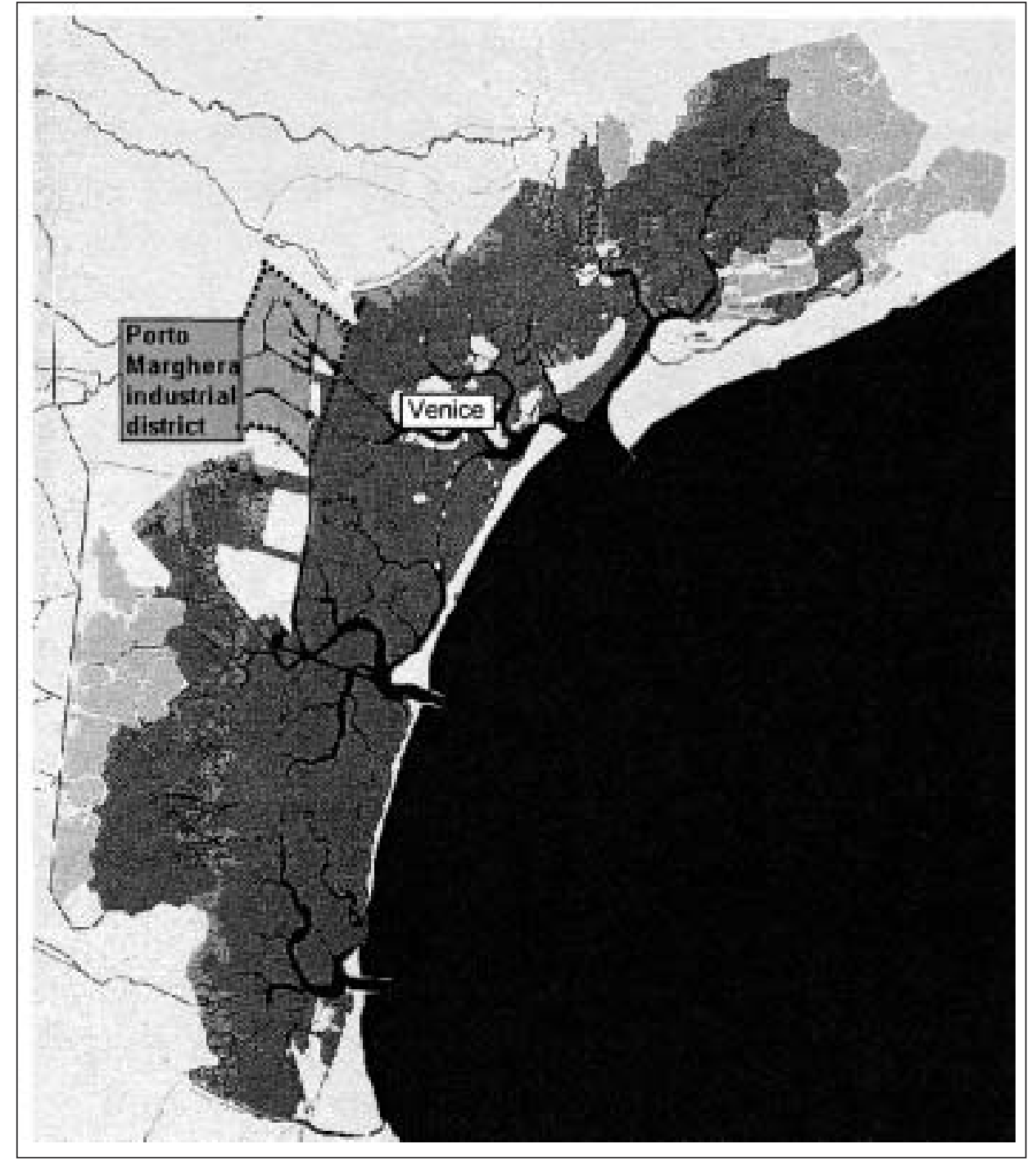

Fig. 1 The study area: the lagoon of Venice, with the indication of the major pollutant sources, such as the industrial district of Porto Marghera, treated and untreated sewage discharges, and freshwater tributaries.

The relation between the lagoon contamination and the Porto Marghera industrial district is apparently evident, but not easy to explain in qualitative and quantitative terms, encompassing present activities and legacies of the past. The first industrialization dates back to 1920 , but it was in the 1960s to 1970s that a large portion of salt marshes, at the edge of the lagoon, was reclaimed using dredged sediment and industrial waste to build up the ground for new plants. The pool of new factories included chemical and petrochemical plants, thermal power plants, and productions of steel, aluminum and fertilizers. Moreover, the industrial port extended over approx. 340 ha of navigable canals connected with the sea through the three lagoon inlets.

The investigation of the industrial site showed a severe chemical contamination of soil, groundwater and sediments of industrial canals. Therefore, beside the emissions of current industrial activities, the quality of lagoon waters and sediments is heavily af- fected by contact (water/soil partition and sediment resuspension and transport) with contaminated sediments in the industrial canals, aqueous and solid run off, and groundwaters from the industrial district. Major identified pollutants included polychlorinated dioxins/furans (PCDD/Fs), polychlorinated biphenyls (PCBs), polycyclic aromatic hydrocarbons (PAHs), and metals/metalloids such as arsenic, mercury, nickel, cadmium, chromium, and lead. In addition to these well-known contaminants, new classes of pollutants, especially endocrine disrupting compounds (EDCs), were more recently investigated.

\section{Analytical and Environmental Chemistry}

A large variety of chemicals must be analyzed in both biotic (organisms) and abiotic (water, particulate matter, sediment) compartments in order to assess the overall 
impact of pollutants on an ecosystem. Compounds of concern need to be selected according to criteria related with persistence, toxicity and bioaccumulation properties of the chemicals. Matrix effects, moreover, can severely influence analytical performances, such as selectivity, sensitivity, accuracy, and precision. Although major attention was given to persistent organic compounds such as polycyclic aromatic hydrocarbons (PAHs), polychlorobiphenyls (PCBs), and polychlorodibenzodioxins and furans (PCDD/Fs), halogenated hydrocarbons, other chemicals (e.g. surfactants, organic additives, etc.) biodegradable and less toxic, but released to a higher extent can pose supplementary adverse effects on aquatic ecosystems. When strict relationships between specific contaminants and sources exist, selected pollutants can be used as 'molecular markers' [3]. For instance, surfactants are typical anthropogenic 'molecular markers' of both municipal (linear alkylbenzene sulphonates, LAS; alcohol polyethoxylates, alcohol polyethoxylate sulphates, AES) and industrial (nonylphenol polyethoxylates, NPE; multibranched AE) discharges: spatial distribution of parent compounds and biodegradation intermediates can supply information on potential pollution sources, hydrodynamics and self-purification capability of an aquatic ecosystem. In addition to the well-known contaminants, 'new' pollutants are triggering increasing interest because of their potential ubiquitous presence in waters and their possible effects on organisms: endocrine disrupting compounds (EDCs) [4][5]. Nowadays, thousands of compounds (pesticides, alkylphenols, dioxins, synthetic steroids, PAHs, hydroxylated PAHs) are demonstrated or suspected to modulate or mimic the actions of steroidal hormones and induce biological effects (such as reduced fecundity and/or fertility, abnormally elevated levels of plasma vitellogenin and intersex gonads) similar to those produced by endogenous hormones, even at ng/l and sub-ng/l levels [6-8]. All these effects can cause an increase in the feminization process that is very dangerous for the survival of species and ecosystems, as they necessarily lead to a loss of biodiversity. Despite the potential impact of these compounds on the environment, only a small number of EDCs have been included so far in international conventions and priority pollutant lists [9][10].

The application of very sensitive methods based on gas chromatography coupled with both low and high resolution mass spectrometry (GC-MS), and inductively coupled plasma-mass spectrometry (ICP$\mathrm{MS}$ ), enabled an inventory of occurrence and distribution of metals, PAHs, PCBs, and PCDD/Fs in the Venice lagoon sediments and biota to be obtained [11-17]. The exposure to PCDD/Fs and dioxin-like PCBs was obtained by applying the TEQ (Toxic Equivalent) approach [18]. Typical mean concentration of total PCBs and PCDD/Fs in the central lagoon sediments, affected by both industrial and municipal activities, were $8.5 \mu \mathrm{g} / \mathrm{kg}$ d.w. and $300 \mathrm{ng} / \mathrm{kg}$ d.w. (6.1 ng TEQ/kg d.w.) respectively [17].

The field application of specific methods based on high-pressure liquid chromatography (HPLC) coupled with both fluorescence and mass spectrometry detectors [19-22] for the determination of surfactants, permitted the disclosure of the occurrence and distribution of LAS, NPE, and their major metabolites (sulphophenylcarboxylates, SPC; NP and carboxylated nonylphenol polyethoxylates, NPEC, respectively) in the Venice lagoon. Concentrations of these 'molecular markers', in the $1.4-14 \mu \mathrm{g} / \mathrm{l}$ range and $1.2-6.8 \mu \mathrm{g} / \mathrm{l}$ for LAS and NPE, respectively [23], revealed a regular re-distribution of municipal and industrial effluents inside the lagoon due to the distinctive hydrodynamics of this ecosystem.

More recently, analytical methods were developed, based on SPE-HPLC-ESI-MS, for the simultaneous determination in the Venice lagoon waters, sediments and organisms of natural (estradiol, E2; estriol, E3; estrone, E1) and synthetic estrogenic disrupting compounds (EDCs), both steroidal (ethinylestradiol, EE2; mestranol, MES) and non-steroidal (benzophenone, BP; bisphenol-A, BPA; diethylstilbestrol, DES; octylphenol, OP; nonylphenol, NP; nonylphenol monoethoxylate carboxylate, NP1EC). The selected EDCs were chosen to cover most potential sources expected to affect the selected ecosystem, such as the historical center of Venice (steroidal EDCs, DES) and the industrial area (non-steroidal EDCs).

No significant differences in the EDC distribution were observed between examined sources, such as inner canals of the historical center, effluents from mechanicalbiological sewage treatment plants (STPs), and rivers flowing into the lagoon. While synthetic non-steroidal EDCs were recorded in the 3-1000 ng/l range, steroidal EDCs (estradiol, estrone, ethinylestradiol) concentrations were lower (0.9-34 ng/l) [24].

An estimation of the potential exposure of the Venice lagoon organisms towards EDCs was performed by applying the EEQ (Estradiol Equivalent) approach. Steroidal EDCs contributed $>99 \%$ to the total estrogenicity of the waters, in the 4-47 ng/l EEQ range. These EEQ levels are likely to pose adverse effects on aquatic organisms, according to literature [25][26]. The Table shows concentration levels of selected pollutants in the Venice lagoon.

\section{Statistical and Spatial Analysis}

In order to characterize environmental compartments in terms of contamination sources and pathways, the results provided by analytical and environmental chemistry were treated by applying explorative and multivariate statistics as well as geostatistics and GIS.

Explorative statistical analysis provided the data probability distribution and statistical correlation between investigated parameters (e.g. pollutants concentration in environmental matrices, etc.). The application of multivariate analysis, by means of a wide variety of multivariate techniques such as Cluster Analysis, Principal Component Analysis (PCA), and Canonical Analysis (CA), resulted in a useful tool for the formulation of hypotheses about pollution sources and pollutants environmental fate [27].

Then the statistical analysis results were integrated by spatial analysis, which was accomplished by geostatistics in a GIS framework, including variography and kriging [28]. Geostatistics is based on spatial relationships between georeferenced data, such as environmental data, and provides tools for data interpolation (2D and 3D kriging, starting from determination of spatial autocorrelation, i.e. variography), as well as for the uncertainty estimation. The latter may highlight environmental areas where new investigations are required in order to reduce uncertainty itself. Finally, the integration of geostatistics in a GIS permits the georeferenced database management and the mapping overlay, integrating different information in a single framework.

The described tools were applied to the contaminated soils of the Porto Marghera industrial district and contaminated sediments of the Venice lagoon. The application of multivariate statistical analysis, in particular PCA, contributed significantly to identify sources and transport routes of organic and inorganic pollutants [27]. The application of geostatistics and GIS tools resulted in 2D spatial distribution maps of pollutants both in soil and in sediments. As an example, a map of PAHs spatial distribution in the lagoon sediment is presented in Fig. 2. In addition, the application of geostatistics estimated more accurately the pollutant load in the lagoon sediment [29]. 
Table. Concentrations (minimum, maximum, mean) of selected pollutants in water, sediment and organisms of the Venice lagoon (Italy); $\mathrm{n}=$ number of samples analyzed

\section{Compound}

Mercury in sediments $(n=64)$

Mercury in filter feeders (Tapes ph., $\mathrm{n}=23$, Mytilus galloprovincialis, $\mathrm{n}=7$ )

Mercury in fish (Zosterisessor ophiocephalus, $n=8$, Chelon labrosus, $n=4$ )

Arsenic in sediments $(n=64)$

Arsenic in filter feeders (Tapes ph., $\mathrm{n}=23$, Mytilus galloprovincialis, $\mathrm{n}=7$ )

Arsenic in fish (Zosterisessor ophiocephalus, $n=8$, Chelon labrosus, $n=4$ )

Polycyclic aromatic hydrocarbons (PAHs) in sediments $(n=64)$

Sum of dioxin-like polychlorobiphenyls (PCBs) congeners ${ }^{b}$ in sediments ${ }^{c}(n=64)$

Sum of dioxin-like polychlorobiphenyls (PCBs) congeners ${ }^{b}$ in filter feeders ${ }^{c}$

(Tapes ph., $\mathrm{n}=23$, Mytilus galloprovincialis, $\mathrm{n}=6$ )

Sum of dioxin-like polychlorobiphenyls (PCBs) congeners ${ }^{b}$ in fish ${ }^{c}$

(Zosterisessor ophiocephalus, $\mathrm{n}=8$, Chelon labrosus, $\mathrm{n}=6$ )

Polychlorodibenzodioxins/furans $\left(2,3,7,8\right.$ PCDD/Fs) in sediments ${ }^{c}(n=64)$

Polychlorodibenzodioxins/furans (2,3,7,8 PCDD/Fs) in filter feedersc ${ }^{1}$

(Tapes ph., $\mathrm{n}=23$, Mytilus galloprovincialis, $\mathrm{n}=6$ )

(Zosterisessor ophiocephalus, $\mathrm{n}=8$, Chelon labrosus, $\mathrm{n}=6$ )

Endocrine Disrupting Compounds (EDCs) ${ }^{d}$
Polychlorodibenzodioxins/furans (2,3,7,8 PCDD/Fs) in fish ${ }^{1}$

\begin{tabular}{llll} 
Unit & \multicolumn{2}{l}{ Concentration } \\
& Min & Max & Mean \\
$\mathrm{mg} / \mathrm{kg}, \mathrm{dw} w^{\mathrm{a}}$ & 0.1 & 2.9 & 0.7 \\
$\mathrm{mg} / \mathrm{kg}, \mathrm{ww}$ & 0.02 & 0.11 & 0.05 \\
$\mathrm{mg} / \mathrm{kg}, \mathrm{ww}$ & 0.05 & 0.24 & 0.11 \\
$\mathrm{mg} / \mathrm{kg}, \mathrm{dw}$ & 5 & 38 & 11 \\
$\mathrm{mg} / \mathrm{kg}, \mathrm{ww}$ & 1.5 & 10.7 & 3.3 \\
$\mathrm{mg} / \mathrm{kg}, \mathrm{ww}$ & 1.2 & 13.5 & 3.4 \\
$\mathrm{mg} / \mathrm{kg}, \mathrm{dw}$ & 50 & 27300 & 418 \\
$\mathrm{ng} / \mathrm{kg}, \mathrm{dw}$ & 0.005 & 0.15 & 0.024 \\
$\mathrm{ng} / \mathrm{kg}, \mathrm{ww}$ & 0.00028 & 2.77 & 0.178 \\
$\mathrm{ng} / \mathrm{kg}, \mathrm{ww}$ & 0.53 & 5.07 & 1.78 \\
$\mathrm{ng} / \mathrm{kg}, \mathrm{dw}$ & 0.3 & 27 & 3.8 \\
& & & \\
$\mathrm{ng} / \mathrm{kg}$ ww & 0.04 & 1.44 & 0.26 \\
$\mathrm{ng} / \mathrm{kg}$ ww & 0.21 & 1.00 & 0.49 \\
$\mathrm{ng} / \mathrm{l}$ & 4.3 & 47 & 20
\end{tabular}

adw: dry weight; ww: wet weight

bSum of PCBs \# 77, 81, 105, 114, 118, 123, 126, 156, 157, 167, 169, 189

${ }^{\mathrm{C}}$ As TEQ (Toxic Equivalent)

${ }^{\mathrm{d} A s}$ EEQ (Estradiol Equivalent) of estradiol, estrone, ethynylestradiol, mestranol, benzophenone, bisphenol-A, diethylstilbestrol,

octylphenol, nonylphenol, nonylphenol monoethoxylate carboxylate

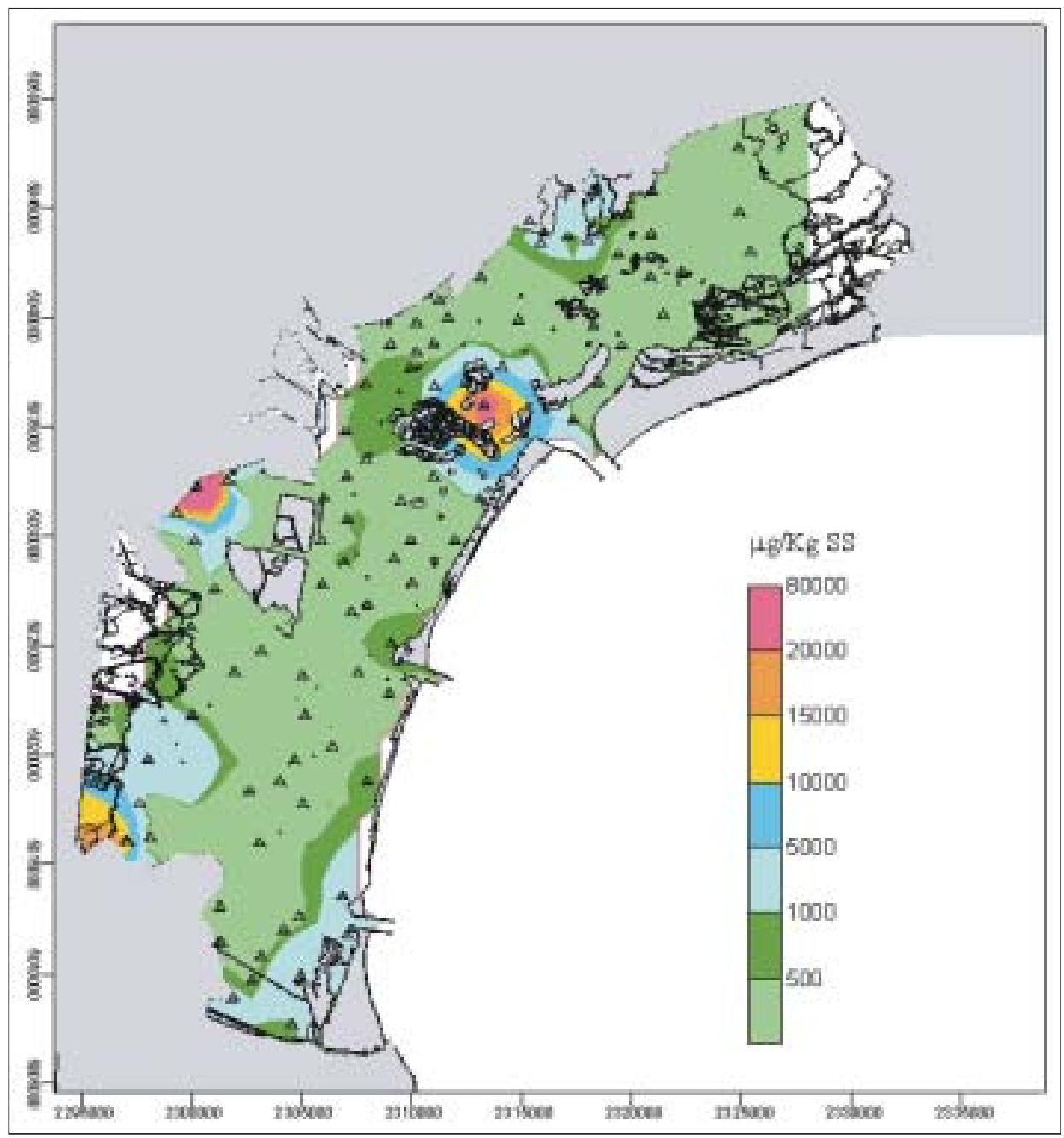

Fig. 2. Contour map of PAHs spatial distribution in lagoon sediments, obtained by kriging interpolation. 
Spatial distribution maps, integrated by information about main sources and pathways of pollutants, provided a suitable tool for exposure characterization; a major step in Environmental Risk Assessment, described in the following paragraph.

\section{Environmental Risk Assessment}

Chemical data elaborated by means of statistical and spatial analysis to characterize the contamination in terms of sources, pathways and pollutants concentration in each environmental compartment, provided the basis for undertaking the Environmental Risk Assessment (ERA). Risk posed by pollutants for both human and environmental health was estimated by applying international procedures [30-32], which are generally structured in four phases: Problem Formulation, Exposure Characterization, Effect Characterization, and Risk Characterization.

In the Problem Formulation phase, information about environmental receptors and stressors were utilized to define the conceptual model, which disclosed the selected risk scenarios highlighting source, pathway and target of stressors.

In the Exposure Characterization phase, environmental fate and transport of pollutants were estimated by means of the Mackay fugacity models [33][34], estimating pollutant equilibrium concentrations in environmental matrices (e.g. water, particulate matter). The bioaccumulation of pollutants in organism tissues was estimated by bioaccumulation models, such as spatial regression models, based on spatial regression analysis [35], and the partitioning Food Chain bioaccumulation model [36].

Human health exposure was obtained by applying well-known Risk Assessment models, such as $\mathrm{RBCA}^{\oplus}$ [37], API-DSS ${ }^{\odot}$ [38], and Risk Assistant ${ }^{\circledR}$ [39]. The risk posed to human health was inferred by comparing the estimated intake dose by Reference Dose for non-carcinogenic substances or Slope Factor for carcinogenic substances.

Ecological Effects Characterization within the Environmental Health Risk was found to be the most challenging issue in risk assessment, especially because a hightier risk assessment requires site-specific effects data on representative organisms of the studied ecosystem. The approach applied by our research group was the integration of data from different sources, such as site-specific (biomarkers and bioassays) and literature toxicity data, Ambient Quality Criteria [40] and estimated Critical Body Burden [41][42].
This activity prompted to obtain sitespecific toxicity data for the lagoon of Venice, especially those concerning spermyotoxicity and embryotoxicity bioassay on sea urchin [43], and selected biomarkers (e.g. neutral red test) for Mytilus galloprovincialis (stress indices) [44].

\section{Data Integration and ERA Application to Case Studies}

According to the TRIAD approach (a procedure integrating chemistry, ecology, and ecotoxicology) [45], exposure and effects data (i.e. lines of evidence) may be grouped into three disciplines: chemistry (e.g. bioavailability), toxicology (e.g. biomarker, bioassay) and ecology (e.g. Integrity Biotic Index [46]). The integration of results from the TRIAD activities, selected according to appropriate criteria (e.g. sensitivities, economic cost, etc.), provides risk estimation. In particular, the development of a Weight of Evidence approach [47] permits the evaluation, integration and weighting of exposure and effects lines of evidence (i.e. endpoints) to obtain the qualitative or quantitative risk.

An ERA (Ecological Risk Assessment) procedure for contaminated soil and sediment was developed according to a tiered approach, including scooping, screening and site-specific risk analysis, the latter being developed according to the TRIAD approach (ANPA, 2002 [48]). Efforts focused especially on the integration of spatial analysis into risk assessment procedures by using spatial regression and geostatistics as GIS tools [49].

Moreover, a novel procedure, named Strategic Risk Assessment, was recently developed to analyze and represent the spatial distribution of human health and ecological risk posed by contaminants in soil and groundwater [50][51]. Whereas traditional risk assessment procedures provide an average estimation of the risk posed by contaminated sites, the strategic risk assessment procedure allows the identification of risk hot spots within a large contaminated area, in order to define priorities and aspects of special concern (pollutants, receptors, exposure pathways) for planning remediation interventions. This procedure was applied to the Porto Marghera industrial district and provided priorities and objectives of remediation for the protection of human health and the lagoon water quality [51].

Ecological risk procedures were applied to the lagoon of Venice. The anthropogenic and natural stressor factors, the stressors and the potential adverse effects on ecolog- ical resources (i.e. assessment endpoints) were disclosed by the conceptual model. An ERA for the benthic community, the edible clam Tapes philipinarum and the aquatic food web was undertaken to estimate the risk posed by the pollutants stored in sediments. Exposure was characterized by applying spatial distribution maps of pollutant concentration in sediments and in organisms, while the effects were estimated by means of Ambient Quality Criteria and Critical Body Burden through the TSCs approach [41]. Finally, risk was estimated by applying the Toxic Unit approach [52], resulting in graphs such as that in Fig. 3B, showing the Unit Toxic sum along the landside and sea-side transects reported in Fig. $3 \mathrm{~A}$.

\section{Definition of Decision Support Systems}

Risk assessment provides a rational basis for the definition of environmental management policies. With the objective of the risk minimization, actions can be taken either to remove the contamination source, or to reduce the exposure. This final phase is called risk management, and should be regarded separately from the risk estimation, as it involves decision makers and technological, economical, social, and political issues. The major task of scientists is to provide all relevant information in a manageable form for decision-making. For this purpose, specific tools can be developed, such as Decision Support Systems (DSSs). DSSs are not intended for providing solutions, i.e. replacing decision makers, but for identifying realistic choices and integrating information into a coherent framework suitable for analysis and selection of alternatives. A risk assessment was first included within a risk management framework, and then a risk-based decision support system was developed [52]. This effort required close collaboration among different experts, such as environmental chemists, GIS specialists, risk assessors, multi-criteria analysts and economists. The main result was a Decision Support sYstem for REhabilitation of contaminated megasites, named Desyre [50][51]. The Desyre DSS integrates risk, technological and socioeconomical assessment procedures within a GIS framework. It is based on a relational database of environmental data (more than 3000 sampling points), available information on technology performance (more than 60 remedial technologies), and socio-economic factors affecting the suitability of the site for future redevelopment. Based on the multi-criteria analysis of human health risk 


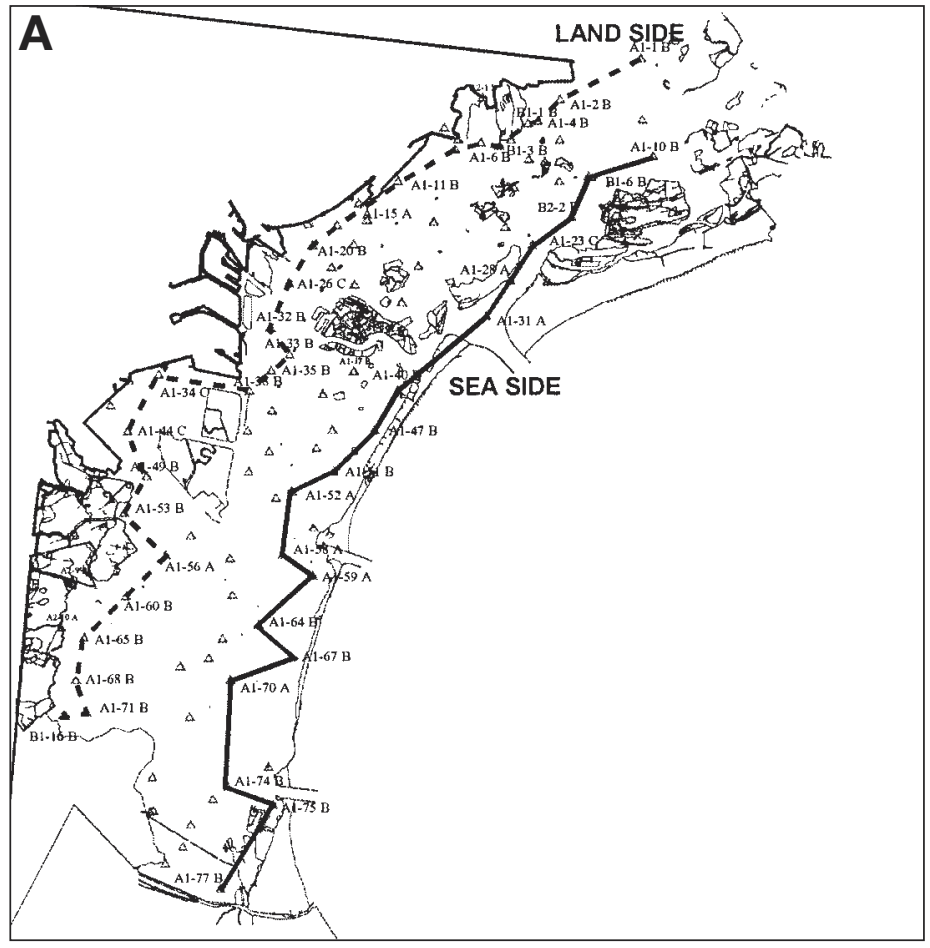

Fig. 3. A. Transects, i.e. land-side (dashed line) and sea-side (plain line), used for benthic community risk assessment by the Toxic Unit method.

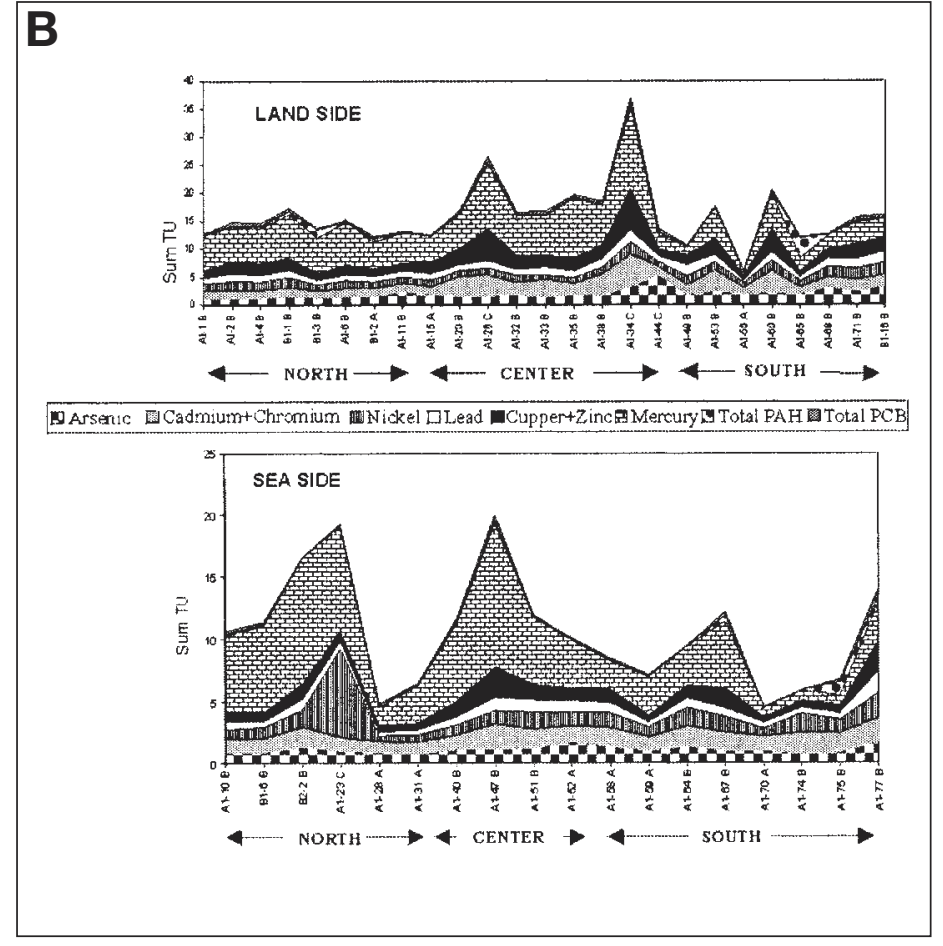

B. Toxic Unit sum of arsenic, cadmium, chromium, nickel, lead, copper, zinc, mercury, total PAHs and total PCBs along the land-side and sea-side transects.

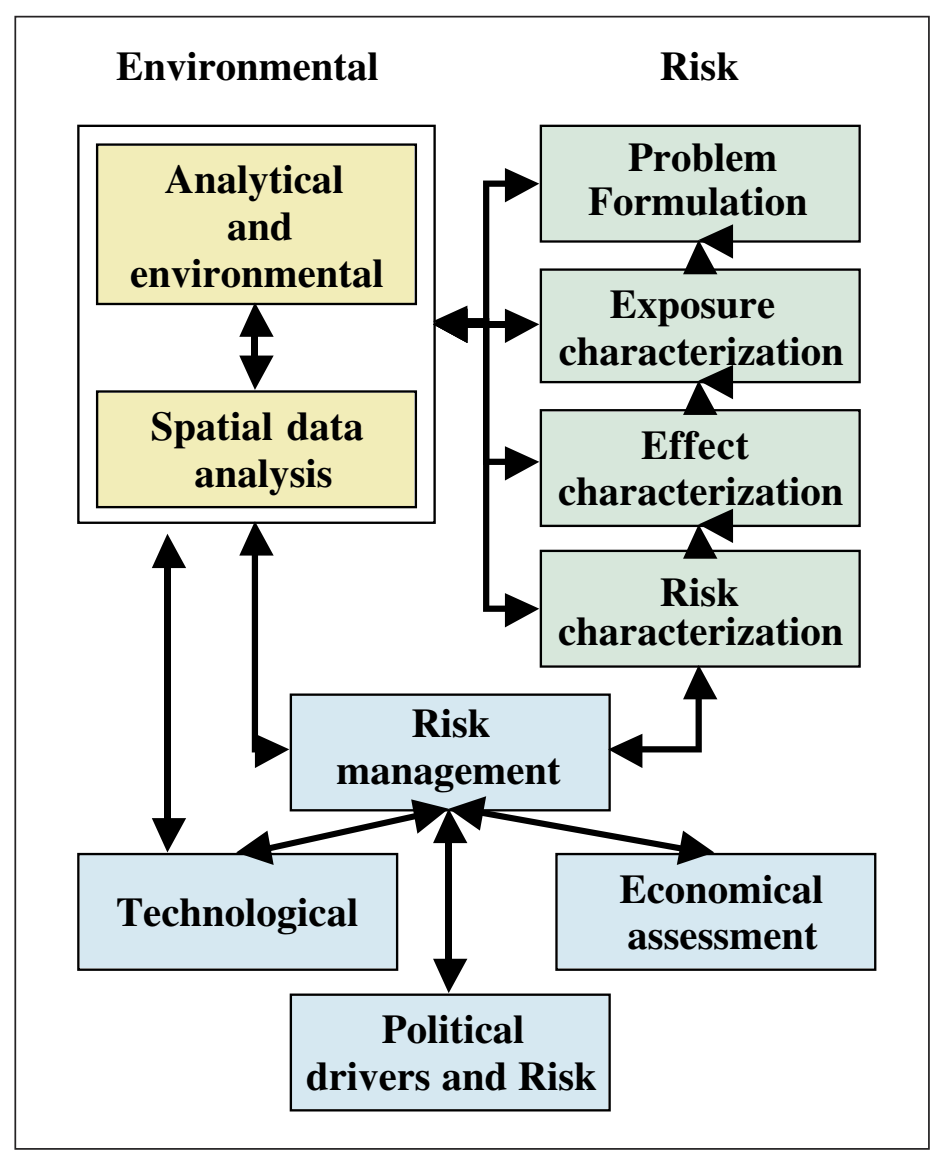

Fig. 4. Integrated approach proposed for the assessment and management of toxic and persistent pollutants in the environment. 
assessment, geological and hydrogeological characteristics of the site, and the type of contaminants, a selection of suitable technologies can be performed. The simulation of different technological solutions provide information about the residual contamination and risk at the site, costs, time and environmental impacts. Alternative solutions can be compared by means of risk, technological and economical indicators.

\section{Conclusion}

In our laboratory, analytical and environmental chemistry research has been addressed over the last ten years to risk assessment and management needs, which has led to the creation of an interdisciplinary team, and to the development of problem-oriented research. Gradually moving from the identification and quantification of contaminants in environmental matrices to the development of decision support systems, the main steps shown in Fig. 4 can be identified, generating several benefits to environmental chemistry. Major benefits concerned the selection of priority pollutants, the optimization of sampling design, the development of highly sensitive and selective analytical procedures, and the identification of critical environmental pathways. These benefits significantly concurred to the uncertainty minimization correlated with the overall decisional process and to cost-saving, thus improving the management of toxic and persistent substances in the lagoon of Venice.

Received: July 19, 2003

[1] S. Vazzoler, F. Costa, S. Bernardi, Istituto Veneto di Scienze ed Arti, Venice, Italy, 1987.

[2] Law 426/98, 9th December. New environmental interventions. Italian Legislation Gazette n. 291, 14th December 1998.

[3] H. Takada, R.P. Eganhouse, 'Molecular markers of anthropogenic waste', in 'Encyclopedia of environmental analysis and remediation', John Wiley \& Sons, New York, USA, 1998, pp. 2883-2940.

[4] C.E. Purdom, P.A. Hardiman, V.J. Bye, N.C. Eno, C.R. Tyler, J.P. Sumpter, 'Estrogenic effects of effluents from sewage treatment works', Chemical Ecology 1994, 8, 275-285.

[5] W. Körner, P. Spengler, U. Bolz, W. Schuller, V. Hanf, J. Metzger, 'Substances with estrogenic activity in effluents of sewage treatment plants in southwestern Germany. 2. Biological analysis', Environmental Toxicology and Chemistry 2001, 20, 2142-2151.

[6] S. Jobling, M. Nolan, C.R. Tyler, G. Brighty, J.P. Sumpter, 'Widespread sexual disruption in wild fish', Environmental
Science and Technology 1998, 32, 2498-2506.

[7] W. Körner, V. Hanf, W. Schuller, C. Kempter, J. Metzger, H. Hagenmaier, 'Development of a sensitive E-Screen assay for quantitative analysis of estrogenic activity in municipal sewage plant effluents', The Science of the Total Environment 1999, 225, 33-48.

[8] B. Gutendorf, J. Westendorf, 'Comparison of an array of in vitro assay for the assessment of estrogenic potential of natural and synthetic estrogens, phytoestrogens and xenoestrogens', Toxicology 2001, 166, 79-89.

[9] 'Towards the establishment of a priority list of substances for further evaluation of their role in endocrine disruption', Final report, M0355008/1786Q/10/11/00, European Commission DG ENV, 10 November 2000, Delft, The Netherlands.

[10] Commission of the European Communities. Communication from the Commission to the Council and the European Parliament, COM (1999) 706 final, Bruxelles, 1999.

[11] A. Marcomini, V. Bonamin, S. Degetto, A Giacometti, 'Occurrence of organochlorine pollutants in three dated sediment cores from the lagoon of Venice', Organohalogen Compounds 1999, 43, 373-382.

[12] A. Marcomini, S. Della Sala, G. Ferrari, A Giacometti, S. Guerzoni, S. Raccanelli, R. Zonta, 'Preliminary budget of dioxins and dioxin-like PCBs in the lagoon of Venice', Organohalogen Compounds 1999, 41, 481-486.

[13] B. Pavoni, R. Donazzolo, A. Marcomini, D. Degobbis, A.A. Orio, 'Historical development of the Venice lagoon contamination as recorded in radiodated sediment cores', Marine Pollution Bulletin 1987, 18, 18-24.

[14] B. Pavoni, A. Sfriso, A. Marcomini, 'Concentration and flux profiles of PCBs, DDTs, and PAHs in a dated sediment core from the lagoon of Venice', Marine Chemistry 1987, 21, 25-35.

[15] S. Raccanelli, B. Pavoni, A. Marcomini, A.A. Orio, 'Polychlorinated biphenyl pollution caused by resuspension of surface sediments in the lagoon of Venice', The Science of the Total Environment 1989, $79,111-123$.

[16] A. Marcomini, M. Zanette, F. D’Andrea, S. Della Sala, 'Diossine Ambiente e Salute. Stato attuale delle conoscenze e laguna di Venezia', Arsenale Editrice, Venezia, 1997, p. 95

[17] Venice Water Authority (Magistrato alle Acque di Venezia - Consorzio Venezia Nuova). 'Mapping the lagoon bottom sediments contamination' (in italian), Final report, Venezia, 2000.

[18] M. Van den Berg et al., 'Toxic Equivalency Factors (TEFs) for PCBs, PCDDs, PCDFs for humans and wildlife', Environmental Health Perspectives 1998, 106, 775-792.

[19] A. Marcomini, B. Pavoni, A. Sfriso, A.A. Orio, 'Persistent metabolites of alkylphenol polyethoxylates in the marine environ- ment', Marine Chemistry 1990, 29, 307-323.

[20] A. Di Corcia, M. Marchetti, R. Samperi, A. Marcomini, 'Liquid chromatographic determination of linear alkylbenzenesulfonates in aqueous environmental samples', Analytical Chemistry 1991, 63, 1179-1182.

[21] C. Crescenzi, A. Di Corcia, R. Samperi, A. Marcomini, 'Determination of nonionic polyethoxylate surfactants in environmental waters by liquid chromatography/electrospray mass spectrometry', Analytical Chemistry 1995, 67, 1797-1804.

[22] C. Crescenzi, A. Di Corcia, E. Marchiori, R. Samperi, A. Marcomini, 'Simultaneous determination of alkylbenzenesulfonates and dialkyltetralinsulfonates in water by liquid chromatography', Water Research 1996, 30, 722-730.

[23] A. Marcomini, G. Pojana, A. Sfriso, J.M. Quiroga, 'Behaviour of anionic and nonionic surfactants and their persistent metabolites in the Venice lagoon (Italy)', Environmental and Toxicological Chemistry 2000, 19, 2000-2007.

[24] G. Pojana, A. Bonfà, F. Busetti, A. Collarin, A. Marcomini, 'Estrogenic potential of the Venice lagoon waters', Environmental and Toxicological Chemistry 2003, submitted.

[25] J.L. Harries, D.A. Sheahan, S. Jobling, P Matthiessen. P. Neall. J.P. Sumpter, T. Tylor, N. Zaman, 'Estrogenic activity in five United Kingdom rivers detected by measurement of vitellogenesis in caged male trout', Environmental Toxicology and Chemistry 1997, 16, 534-542.

[26] M. Seki, H. Yokota, H. Matsubara, Y. Tsuruda, M. Maeda, H. Tadokoro, K. Kobayashi, 'Effect of ethynylestradiol on the reproduction and induction of vitellogenin and testis-ova in medaka (Oryzias latipes)', Environmental Toxicology and Chemistry 2002, 21, 1692-1698.

[27] J.W. Einax, H.W. Zwanzinger, S. Geib, 'Chemometrics in Environmental Analysis', VCH A Wiley company, Weinheim, 1997.

[28] E.H. Isaaks, R.M. Srivastava, 'An Introduction to Applied Geostatistics', Oxford University Press, Oxford, 1989.

[29] A. Critto, C. Carlon, A. Marcomini, 'Screening ecological risk assessment for the benthic community: the Venice lagoon as case study', Environment International 2003, in press.

[30] U.S. Environmental Protection Agency, 'Risk Assessment Guidance for Superfund (RAGS), Vol I - Human Health Evaluation Manual, Part A', 1989.

[31] ASTM, 'Standard Guide for Risk-based Corrective Action Applied at Petroleum Release Sites - RBCA', E 1739-95, 1995.

[32] U.S. Environmental Protection Agency, 'Guidelines for Ecological Risk Assessment. Washington DC: Risk Assessment Forum', EPA/630/R-95/002F, 1998.

[33] D. Mackay, 'Multimedia environmental models - The Fugacity Approach', Lewis Publishers, 1991.

[34] M. Dalla Valle, A. Marcomini, A. Sfriso, A.J. Sweetman, K.C. Jones, 'Estimation 
of $\mathrm{PCDD} / \mathrm{F}$ distribution and fluxes in the Venice Lagoon, Italy: combining measurement and modelling approaches', Chemosphere 2003, 51, 603-606.

[35] N.A.C. Cressie, 'Statistics for Spatial Data', John Wiley \& Sons, New York, USA, 1993.

[36] A.P.C.F. Gobas, 'A model for predicting the bioaccumulation of hydrophobic organic chemicals in aquatic food-webs: application to Lake Ontario', Ecological Modelling 1993, 69, 1-17.

[37] American Society for Testing and Materials, 'Emergency Standard Guide for RiskBased Corrective Action Applied at Petroleum Release Sites', Designation PS 104, Philadelphia, 1998.

[38] American Petroleum Institute, 'Decision Support System for Exposure and Risk Assessment. Version 1.0', Geraghty e Miller, Inc., Washington D.C., 1998.

[39] K.M. Thompson, 'Software review of Risk*Assistant (Version 1.1) and RiskEZ (Version 1), both for Windows', Human and Ecological Risk Assessment 1998, 4, 647-652.

[40] D.D. MacDonald, 'Approach to the Assessment of Sediment Quality in Florida Coastal Waters', Florida Department of Environmental Protection, Tallahassee, FL., 1994.

[41] B.K. Shephard, 'Quantification of Ecological Risks to Aquatic Biota from Bioaccumulated Chemicals', in 'National Sediment Bioaccumulation Conference', EPA823-R-98-002, February 1998.

[42] A.P. van Wezel, M.T.O. Jonker, 'Use of the lethal body burden in the risk quantification of field sediments; influence of temperature and salinity', Aquatic Toxicology 1998, 42(4), 287-300.

[43] A.V. Ghirardini, A.A. Novelli, B. Likar, G Pojana, P.F. Ghetti, A. Marcomini, 'Sperm cell toxicity test using sea urchin Paracentrotus lividus Lamarck (Echinodermata: Echinodea): sensitivity and discriminatory ability towards anionic and nonionic surfactants', Environmental and Toxicological Chemistry 1999, 32, 711-718.

[44] C. Nasci, L. Da Ros, G. Campesan, V.U. Fossato, 'Assessment of the impact of chemical pollutants on mussel, Mytilus galloprovincialis, from the Venice Lagoon, Italy', Marine Environmental Research 1998, 46, 279-282.

[45] P.M. Chapman, 'The Sediment Quality Triad: then, now and tomorrow', International Journal of Environment and Pollution, 2000, 13(1-6), 351-356.

[46] J.R. Karr, E.W. Chu, 'Biological Monitoring and Assessment: Using Multimetric Indexes Effectively', EPA 235-R97-001, University of Washington, Seattle, 1997.

[47] Massachusetts Weight-of-Evidence Workgroup, 'A Weight-of-Evidence approach for evaluating ecological risks', Draft Report, November 2, 1995.

[48] F. Quercia, A. Marcomini, A. Critto, C Carlon, 'Ecological risk assessment applied to contaminated sites: review of international regulatory approaches and proposal of a national procedure', Manual and guidelines n. 11/2002, ANPA - Italian Na- tional Agency for Environmental Protection, Rome, Italy, p. 1-104 (in Italian), 2002.

[49] C. Micheletti, A. Critto, C. Carlon, A Marcomini, 'Ecological Risk Assessment of persistent toxic substances for the clam Tapes philipinarum in the lagoon of Venice', Environmental Toxicology and Chemistry 2003, submitted.

[50] C. Critto, S. Giove, N. Nadal, M. Samiolo, C. Carlon, S. Silvani, S. Foramiti, A. Marcomini, 'Desyre - Decision Support sYstem for Rehabilitation of contaminated sites: integration of multi-criteria Decision Analysis tools', Peer Review Extended Acts, 'IEMSs International Conference of Environmental Modelling and Softwares', Lugano, June 2002.

[51] C. Carlon, A. Critto, N. Nadal, M. Samiolo, A. Marcomini, G.A. Petruzzelli, 'Desyre - decision support system for rehabilitation of contaminated sites', Consoil 2003 8th International Conference on Contaminated Soil, Gent, 12-16 May 2003, Extended proceedings.

[52] P.M. Chapman, M. Cano, A.T. Fritz, C. Gaudet, C.A. Mencie, M. Sprenger, W.A. Stubblefield, 'Summary report on contaminated site cleanup decisions', in 'Ecological risk assessment of contaminated sediments', SETAC Press, 1997, p. 83-114. 